\title{
Advances In Natural And Applied Sciences
}

2018 March; 12(3): pages 66-70

DOI: $10.22587 /$ anas.2018.12.3.11

\section{Leadership Skills Requirements for Military Cadets}

\author{
${ }^{1}$ Ananthan, S., ${ }^{1}$ Haslinda, A. and ${ }^{1}$ Jegak, U. \\ Faculty of Defence Studies \& Management, National Defence University of Malaysia, Sungai Besi Camp, 57000 Kuala Lumpur, Malaysia
}

Correspondence Author: Ananthan, S., Faculty of Defence Studies \& Management, National Defence University of Malaysia, Sungai Besi Camp, 57000 Kuala Lumpur, Malaysia.

Tel: +6019-2385698; E-mail: ananthan@upnm.edu.my

Received date: 12 January 2018, Accepted date: 10 March 2018, Online date: 20 March 2018

Copyright: (C) 2018 Ananthan, S. et al. This is an open-access article distributed under the terms of the Creative Commons Attribution License, which permits unrestricted use, distribution, and reproduction in any medium, provided the original author and source are credited.

\begin{abstract}
Most militaries train their officers through an officer cadet system at their respective military academies. The process, which takes between three and four years, requires all cadets to possess basic leadership skills before they are commissioned into their respective armed forces. This study endeavoured to determine the leadership skills requirements of newly commissioned young officers from the military academy. First, academic literature and military doctrine were surveyed to derive current notions of leadership skills at the junior level. Subsequently, high ranking military officers were interviewed to determine the armed forces' expectation of leadership competencies amongst junior officers. Both sets of findings were analysed to create a questionnaire instrument. This instrument was administered to mid-level career officers ( $n=513$ ), as they were direct supervisors of these young officers. The analysis of this survey revealed a list of twelve leadership skills expected of junior officers and the level of competency expected of each leadership skill. Using this list, instructors at the military academy were then requested to gauge the level of each leadership skill attained by officer cadets as they finished their three-to four-year training. Based on what was expected and what was attained, the gap in leadership skills of junior officers was determined. This finding is a significant contribution towards the review and enhancement of current curriculum for leadership skills development at the military academy.
\end{abstract}

Key words: Leadership Skills; Leader Development; Military Cadets; Armed Forces

\section{INTRODUCTION}

Defence forces are unique organisations in terms of their roles and functions. These forces are typically made up of three services, namely the army, navy and air force. Each of these services has their own distinct culture. However, the ultimate mission of these very dissimilar organisations is to fight wars and win battles, while protecting the sovereignty and territorial integrity of the nation [1]. Besides these important tasks, the armed forces are often called upon to undertake many other missions under the context of Military Operations Other Than War (MOOTW). This covers a wide array of missions from counterinsurgency operations, aid civil authority to overseas peacekeeping missions [2-3]. Given this scenario, leaders at all levels of military command - strategic, operational and tactical (direct) - face increasingly serious challenges in their everyday responsibilities [4]. The prospect of junior unit leaders facing pressure to make urgent and difficult decisions, operations affecting civilians and the trend of near real-time media coverage create a situation where tactical decisions can have unintended strategic consequences [5]. Thus, unlike academic literature which classifies leadership at the first stage as 'novice' [6], young officers joining the armed forces often need to possess greater leadership skills to undertake their functions. The nature of the operational environment calls for them 'to hit the ground running' immediately after being commissioned as officers. They are expected to lead men and women to achieve difficult and challenging tasks almost instantly upon joining their respective units. According to the United States Army Leadership manual, an army officer will require mastery of a full range of leadership skills. To achieve this, they are placed in various positions throughout their career, doing jobs both in the office and in the field. They learn the various leadership skills through job experience and socialisation with their superiors, peers and subordinates [4].

Researchers have studied leadership skills since the early 1950s [3]. Leadership is generally defined as the ability to use one's knowledge and competencies to accomplish a set of organisational goals and objectives [3]. According to Junarso [8], certain skills are required to be an effective leader. Some of these skills come quite naturally, while others require extensive learning and practice. Junarso also maintains that leadership competencies (knowledge and skills) acquired through this process are later demonstrated in the performance of leader tasks and functions.

Moore and Rudd [9] state that there is no one set of leadership competencies that is applicable to all organisations. Pernick [10] concluded that each organization or industry would have its own leadership requirements. This is essentially true, as the nature and priority of tasks in each domain require leaders to possess skills that are specific to the challenges faced. Mumford and Peterson [11] suggest that demands made on the task must first be analysed in order to determine the skills and knowledge required for effective performance in that field. Based on this premise, this study set out to research and determine the leadership skills expected of junior military officers in performing their multifarious tasks and assignments upon completing their training at the military academy and joining the armed services. The specific objectives of this study are to define Armed Forces' expectations of the leadership skills of newly commissioned officers, to identify leadership competencies portrayed by officers commissioned at the military academy and to determine the gap between the desired leadership competencies of MAF and those that are portrayed by officers commissioned at the military academy. 

66-70.

\section{Leader Skills:}

Katz's [12] seminal paper on management skills provided impetus to the skill-based approach in analysing leadership at a time when leadership ability was thought to be dependent on a set of traits. Katz held the opinion that leadership capacity can be developed through a set of 'developable skills'. Based on his extensive research and observation, he concluded that leadership (or management) required three fundamental skills: technical, human and conceptual skills. However, the demand on each skill varies with the level of leadership within an organisation. Since the 1990s, more studies have been conducted to demonstrate the importance of leadership skills in predicting leadership performance. Similar to the conception of Katz, Goleman [13] defined leadership skills as being made up of three domains consisting of technical and conceptual skills and emotional intelligence (EI) competencies. Sub-domains of EI are: self-awareness, selfregulation, motivation, empathy, and social skills. Knowledge in this area was further enhanced through a skill-based theory of leadership development put forth by Mumford and associates, as shown by the model in Figure 1 [14]. This theory was confirmed in many aspects through a significant longitudinal study in the U.S. Army involving 1,800 officers of various ranks [11]. The findings of the study to determine the specific skills of highly effective leaders in the military were congruent with the skills-based model of leadership. Mumford and colleagues, through other related studies, delineated leader competencies into two major skills categories [3]: problem solving (self-awareness, problem construction, creativity) and social judgement (tact, social intelligence, communication, behavioural flexibility).

Individual Attributes

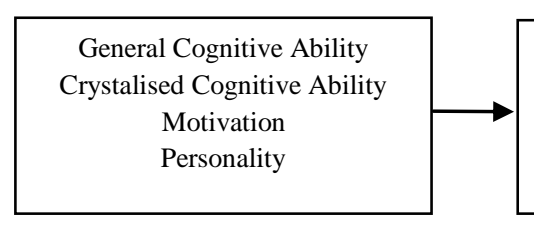

Competencies

Problem Solving Skills Social Judgement Skills Knowledge

\section{Leadership Outcomes}

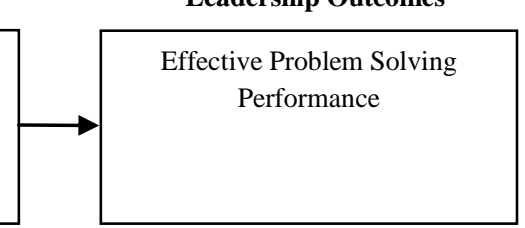

Fig. 1: Skills model of leadership [11, 14]

As well as the academic literature, this study also looked at military doctrines on leadership development. As suggested by Day, Harrison and Halpin [6], even though these military doctrines are usually 'a theoretical', they were based on accepted principles and are philosophically sound. The Malaysia Army Doctrine [15] on leadership recognizes the practice of leadership at three levels: direct, indirect and executive. The direct level refers to junior officers, where leadership is executed at the team level, involving face-to-face contact, requiring good communication and interpersonal skills and personal attention to successful completion of tasks. However, the exact leader competencies and skills are vaguely delineated. The U.S. Army doctrine uses a leadership requirement model to outline attributes and skills [4]. This model suggests that junior leaders require competencies such as leading by example, enforcing standards, motivating, communicating, negotiating, extending influence, developing others, mentoring, developing and executing plans, and building team work. On the other hand, the Malaysian Army doctrine [15] describes leadership skills through four broad categories: conceptual, interpersonal, technical and tactical skills. Based on the survey of academic literature and military doctrines, the leadership skills required for junior military officers is summarised in Table 1.

Table 1: Leadership Skills for Junior Level Military Officers

\begin{tabular}{lll}
\hline & Leadership Skills & Author/Year \\
\hline 1 & Leadership by example & US Army FM 6-22 [4] \\
2 & Effective communications skills & Junarso [8]; MDTD [15]; US Army FM 6-22 [4] \\
3 & Ability to enforce discipline & Junarso [8] \\
4 & Ability to enforce standards & US Army FM 6-22 [4] \\
5 & Ability to plan, organise and execute tasks & Junarso [8]; MDTD [15] 2007; US Army FM 6-22 [4] \\
6 & Ability to motivate & US Army FM 6-22 [4] \\
7 & Ability to mentor subordinates & MDTD [15]; US Army FM 6-22 [4] \\
8 & Team building skills & US Army FM 6-22 [4] \\
9 & Problem solving skills & Junarso [8]; US Army FM 6-22 [4] \\
10 & Negotiation skills & US Army FM 6-22 [4] \\
11 & Interpersonal skills & MDTD [15]; Mumford, Zaccaro, Connelly and Marks [11] \\
\hline
\end{tabular}

These observations about leadership skills and leader development advocate the primary need of the present study: i.e. to determine the exact skills required of young military officers so that appropriate training can be conducted at the military academy.

\section{Objectives:}

The research set out to determine the leadership skills expected of young military officers upon completing their training at the military academy. Accordingly, the objectives outlined for this research are as follows: to define leadership skills expected of newly commissioned officers into the military; to identify leadership competencies portrayed by officers commissioned at the military academy; to determine the gap between the desired leadership competencies and that which is portrayed by officers commissioned at the military academy.

\section{Methodology:} Phase 1:

This study was carried out in several phases employing the following methodologies:

To define the MAF's expectation on leadership competencies of newly commissioned officers, three senior and high-ranking officers (Generals) at the Army, Navy and Air Force HQs were interviewed. The interviewees were purposively selected, as they were deemed to be able to provide authoritative and quality responses based on the key positions they held within the respective service headquarters. The purpose of the interviews was to identify the respective services expected from young military officers, specifically in terms of their leadership skills. Interviews were transcribed to produce a list of measurable skills. This was used to design an instrument to prioritise leadership skills and expected levels.

Phase 2:

The designed instrument was administered to field grade officers - i.e. officers with the rank of Lieutenant Colonel or Major or of equal rank - serving in the armed forces. A convenience sampling technique was used, as all respondents had direct experience in leading and supervising young officers. The purpose of this survey was to determine the preferred/expected leadership skills possessed by young military officers. 

66-70.

The analysis of the responses in Phase 2 was used to develop another set of questionnaires. This instrument was used to evaluate the leadership skills attained by final year officer cadets who had been exposed to the leadership development programme at the military academy in the last three to four years. The evaluation was done by officer instructors (Majors and Captains) who have served in the military academy for more than a year and who knew the individual cadet sufficiently well. A back-translation technique was used to translate the content of questionnaires into Malay to ensure that the questions could be fully understood by the respondents [16].

Interview:

In selecting the interview method, the following three approaches were considered: (a) informal conversational interview, (b) general interview and (c) standardised open-ended interview [17]. Based on a pilot study conducted in a nearby army command headquarters, it was found that senior officers were not keen on following a standardised or structured form of questioning. Thus, taking into consideration the level of seniority of the individuals to be interviewed, the general interview guide approach was used. This approach provided the flexibility to develop rapport with the interviewees and afford them more opportunity to share their thoughts [18]. According to McNamara [19], while providing the interviewees with a level of freedom, the forte of this approach is that it ensures that the researcher remains in control of the areas of focus. This effectively ensures depth and quality of information. Prior to the interviews, participants were sent a summary sheet developed by the researchers based on a literature review (Table 1). The purpose of this summary sheet was to help participants prepare their responses on the types of skills required at the most junior level of the officer corps in the armed forces. The questions developed for the interview were openended and were appraised by several experts for content and face validity. A sample of the questions are as follows: 'What specific leadership skill deficiencies have you observed in young officers? What specific skills do high-performing junior leaders exhibit? What leadership skills do you expect freshly trained military officers to possess? What level of competence do you expect for each skill? Do you see these skills requirements changing in the near future?

\section{Questionnaire:}

Two sets of survey questionnaires were developed specifically by the researchers for this research. Questionnaire Set 1 (S1) was designed to identify the different leader skills expected of junior officers by the armed forces as well as the anticipated competence level of each skill. This instrument had twelve leadership skills items, which were rated on a scale of 1 to 3 (average, above average, high). Questionnaire Set 2 (S2) was designed to evaluate the actual level of leadership skills attained by junior officers at the end of their training at the military academy. The evaluation was carried out using an instrument with only 12 items adopted from S1. Items were measured using a Likert scale of 1 to 5 ranging from low, below average, average, above average and high.

\section{Respondents:}

S1 was administered among field grade officers attending the defence and staff college programmes in 2011/2012/2013. Respondents were primarily obtained using a convenience sampling technique representing various corps of the army and branches of the navy and air force. A total of 546 respondents participated. However, only 513 of the returned responses were usable, yielding a 93.6 percent response rate. A profile of these respondents is shown in Table 2.

Table 2: Profile of Respondents (Field Grade Officers, $n=513$ )

\begin{tabular}{llll}
\hline Respondent Profile & Sub Profile & Frequency & Percentage \\
\hline Rank & Major & 399 & $77.8 \%$ \\
& Lt Col & 114 & $22.2 \%$ \\
Total & & 513 & $100 \%$ \\
Service & Army & 354 & $69.0 \%$ \\
& Navy & 75 & $11.6 \%$ \\
Total & Air Force & 34 & $16.4 \%$ \\
\hline
\end{tabular}

Respondents for S2 were drawn from the instructors at the military academy who evaluated the leadership skills of final year officer cadets prior to their commissioning in January 2014. To reduce inter-assessor bias, they were given a collective briefing and explanation of each item of the instrument. To ensure reliability and randomness, each instructor $(n=22)$ was requested to evaluate a maximum of twenty cadets whom they had known in the last six months. After one week, 402 usable evaluations were collected. For the purpose of analysis, only average scores of cadets who were evaluated by at least two different instructors were used. This criterion effectively reduced the number of evaluated cadets to 176 from a class of 364 officer cadets (48.4\%).

Findings:

Identification of Leader Skills for Junior Officers:

The data collected via the interviews were transcribed and analysed to determined several leadership skills required of junior officers commisioned at the military academy. Basically, those interviewed concurred with the list of leader skills mentioned in the academic literature and military doctrine (Table 1). Two skills not found in the literature - i.e. the ability to command and control and delegating skills - were stressed by all three respondents. This was because the armed forces expect young officers to face difficult challenges which required them "to possess the ability to take charge, be assertive and demanding". Because of the possibility of being assigned numerous responsibilities, the ability to delegate tasks was also deemed to be vital. On the other hand, the ability to enforce standards was removed from the list, as respondents felt that junior officers had to learn and understand organisational standards before they could be expected to enforce them. The list of skills concluded from the interview was used as the items for Questionnaire Set 1.

Leadership Skills Competence Level Expected of Junior Officers:

Field grade officers $(\mathrm{n}=513)$ who participated in the survey generally agreed with all the leadership skills listed in the questionnaire (S1). They expected young officers to be highly competent in six basic leadership skills (mean > 2.33 on a scale of 1 to 3 ). These were: leading by example, effective communication, ability to command and control, ability to enforce discipline, team building and ability to plan and execute tasks. Leading by example was the most highly expected of young officers. This is consistent with a military leadership principle [20] which requires leaders to set the example. Table 3 is a summary of these findings, listed in order of the importance of each skill.

Table 3: Leadership Skills Competence Level Expected of Junior Officers

\begin{tabular}{|c|c|c|c|c|}
\hline & & Mean & SD & Expected Competence Level \\
\hline 1 & Leadership by example & 2.58 & 0.730 & High \\
\hline 2 & Effective communications skills & 2.54 & 0.660 & High \\
\hline 3 & Ability to command and control & 2.52 & 0.654 & High \\
\hline 4 & Ability to enforce discipline & 2.46 & 0.731 & High \\
\hline 5 & Ability to motivate & 2.44 & 0.671 & High \\
\hline 6 & Ability to plan, organise and execute tasks & 2.40 & 0.659 & High \\
\hline 7 & Team-building skills & 2.29 & 0.689 & Above Average \\
\hline 8 & Ability to mentor subordinates & 2.11 & 0.673 & Above Average \\
\hline 9 & Delegating skills & 1.82 & 0.670 & Average \\
\hline 10 & Problem-solving skills & 1.60 & 0.668 & Average \\
\hline 11 & Negotiation skills & 1.60 & 0.639 & Average \\
\hline 12 & Interpersonal skills & 1.58 & 0.642 & Average \\
\hline
\end{tabular}


Leadership Skills Levels Achieved by Final Year Cadets:

S2 was used to determine how final year cadets fared on their leadership skills scales. Scores were rated as low (1.00 - 1.99), average (2.00 - 2.99), above average $(3.00-3.99)$ and high $(4.00-4.99)$. With mean scores between 2.63 and 3.76 , almost all the skills were rated at the average to above average level. Officer cadets achieved 'high' ratings on only one skill: the ability to plan, organise and execute tasks. The findings are as shown in Table 4 below.

Table 4: Rating for Leadership Skills Achieved by Officer Cadets.

\begin{tabular}{lllll}
\hline & Skills & Mean & SD & Achieved Competence Level \\
\hline 1 & Ability to plan, organise and execute tasks & 4.24 & 0.670 & High \\
2 & Effective communications skills & 3.76 & 0.642 & Above Average \\
3 & Problem-solving skills & 3.57 & 0.624 & Above Average \\
4 & Team-building skills & 3.55 & 0.692 & Above Average \\
5 & Leadership by example & 3.55 & 0.625 & Above Average \\
6 & Ability to command and control & 3.53 & 0.631 & Above Average \\
7 & Ability to enforce discipline & 3.53 & 0.623 & Above Average \\
8 & Delegating skills & 3.51 & 0.649 & Above Average \\
9 & Interpersonal skills & 2.91 & 0.653 & Average \\
10 & Ability to motivate & 2.87 & 0.623 & Average \\
11 & Ability to mentor subordinates & 2.85 & 0.613 & Average \\
12 & Negotiation skills & 2.63 & 0.649 & Average \\
\hline
\end{tabular}

Analysis of Leadership Skills Expected and Achieved by Final Year Officer Cadets:

A comparison of the results in Table 3 and Table 4 shows that there is a mismatch between skills which are highly expected and those that have been achieved. This mismatch is reflected in Table 5 below.

Table 5: Comparison Between Expected and Achieved Skills

\begin{tabular}{llll}
\hline & Leadership Skills & Expected Competence Level & Achieved Competence Level \\
\hline 1 & Leadership by example & High & Above Average \\
2 & Effective communications skills & High & Above Average \\
3 & Ability to command and control & High & Above Average \\
4 & Ability to enforce discipline & High & Avere Average \\
5 & Ability to motivate & High & High \\
6 & Ability to plan, organise and execute tasks & High & Above Average \\
7 & Team-building skills & Above Average & Average \\
8 & Ability to mentor subordinates & Above Average & Above Average \\
9 & Delegating skills & Average & Above Average \\
10 & Problem-solving skills & Average & Average \\
11 & Negotiation skills & Average & Average \\
12 & Interpersonal skills & Average & \\
\hline
\end{tabular}

Discussion:

Based on the data collected, some gaps between leadership skills expected and achieved by officer cadets are indicated by the results in Table 5 . This essentially shows a mismatch between what is achieved and what is desired. The ability to lead by example is achieved, but at a rating below what is expected. This skill is very important for junior leaders in the armed forces, as they constantly deal with soldiers in the field. According to Malone [20], operational level leaders are required to function through direct contact with their men. In order to influence their subordinates and achieve desired organisational goals and missions, they are required to set the example and take the lead in most endeavours. As observed by the instructors, officer cadets' ability to command and control their subordinates needs to be further developed. This skill, together with the ability to enforce discipline, is highly expected of young officers by their superiors. A deficiency in these two aspects was also confirmed by the Commanding Officer of the Military Academy (personal communication, May 2, 2012). A lack of this ability will hamper the endeavour of a junior officer to bring his or her unit to higher levels of excellence. Command and Control applies to endeavours undertaken by individuals and organizations. It implies the ability to determine the bounds within which behaviours are to take place [21].

Conclusion:

This research has defined the leadership skills required of newly commissioned officers in the armed forces. It has also identified leadership competencies portrayed by officers commissioned at the military academy and the resultant gap in their skills level. As such, it has implications for the leader development programme at the military academy. As suggested by Ericsson, Prietula and Cokely [22], frequent and deliberate practice is required to achieve proficiency in leadership skills. The military academy can look into the policies, training programme and methodologies to create a better environment for the development of leadership skills among military officer cadets before they are commissioned into the armed forces.

This study contributes to the body of literature, especially leadership studies in the military context. Instead of grouping skills as conceptual, interpersonal, emotional and technical [12], describing the actual skills expected of junior leaders provides a greater understanding for all involved, especially trainers, trainees and stakeholders.

It is imperative that certain limitations of the study are highlighted. Firstly, amongst the field grade officers who participated in the survey (n=513), an overwhelming 69\% were from the Army, as opposed to only $11.4 \%$ from the Navy and $16.4 \%$ from the Air Force. This might have caused a bias in the leadership skills identified, to be that which is expected in the Army unit. Secondly, this study took a cross-sectional approach, measuring the achievement of one cohort only (the 2010/2011 cohort). Thus, the findings may not be reflective of the leader development programme at the military academy, which has been institutionalised since 1995. Thirdly, a greater number of respondents for the interview stage could have yielded a more varied skills requirement. Last but not least, the instructors rating their own cadets could have led to biases. It might be more appropriate for young officers to be evaluated at their respective units after a six to 12-month period.

\section{ACKNOWLEDGEMENT}

The authors would like to acknowledge the Ministry of Higher Education (Malaysian Government) for providing a grant (FRGS/2/2010/SS/UPNM/03/3) as financial support to conduct the research. 


\section{REFERENCES}

[1] Malaysian Ministry of Defence, 2010. National defence policy ( $1^{\text {st }}$ ed). Kuala Lumpur: Haji Jantan.

[2] Ananthan, S., Inderjit, S and Kwong, F.W., 2015. Imposing the human dimension factors in evaluating the command climate in military environment. International Journal of Humanities Social Sciences and Education, 2(1), 272-278.

[3] Northouse, P.G., 2007. Leadership theory and practice (4th Ed). Thousand Oaks, CA: Sage Publications.

[4] US Army Field Manual 6-22, 2006. Army leadership: Competent, confident, and agile. Washington DC: US Government Printing Office.

[5] Romaine, K.A., 2000. Junior leader development: Is the United States Army preparing its lieutenants for success. [Monograph]. Online. http://oai.dtic.mil/oai/oai?verb=getRecord\&metadataPrefix=html\&identifier=ADA397470. Retrieved on $12^{\text {th }}$ March 2016.

[6] Day, D.V., M.M. Harrison and S.M. Halpin, 2009. An integrative approach to leader development: Connecting adult development, identity and expertise. New York: Psychology Press.

[7] Bass, B.M., 2008. The Bass handbook of leadership: Theory, research, and managerial applications (4th ed.). New York: Free Press.

[8] Junarso, T., 2009. How to become a highly effective leader: Ten skills a leader must possess. New York: iUniverse Inc.

[9] Moore, L.L.and R.D. Rudd, 2004. Leadership skills and competencies for extension directors and administrators. Journal of Agricultural Education, 45(3), 22-33. http://dx.doi.org. 10.5032/jae.2004.03022

[10] Pernick, R., 2001. Creating a leadership development program: Nine essential tasks. Public Personnel Management, 30(4): 429-444

[11] Mumford, M.D., S.J. Zaccaro, M.S. Connelly and M.A. Marks, 2000b. Leadership skills: Conclusions and future directions. The Leadership Quarterly, 11(1): 155-170. http://doi.org/10.1016/S1048-9843(99)00047-8

[12] Katz, R.L., 1955. Skills of an effective administrator. Harvard Business Review, 33(1): 33-42.

[13] Goleman, D., 1998. What makes a leader? Harvard Business Review, 76(6): 82-91.

[14] Mumford, M.D., S.J. Zaccaro, F.D. Harding, T.O. Jacobs and E.A. Fleishman, 2000a. Leadership skills for a changing world: Solving complex social problems. The Leadership Quarterly, 11(1): 11-35. http://doi.org/10.1016/S1048-9843(99)00041-7

[15] Malaysian Army Doctrine (MDTD), 2007. Command, leadership \& management (provisional). Kuala Lumpur: Department of Army, Ministry of Defence.

[16] Creswell, J.W., 2014. Research design: Qualitative, quantitative, and mixed methods approaches. California: Sage Publication Inc.

[17] Gall, M.D., J.P. Gall and W. Borg, 2007. Educational research: An introduction (8th ed.). New York: Longman.

[18] Turner, D.W., 2010. Qualitative interview design: A practical guide for novice investigators. The Qualitative Report, 15(3): 754-760. http://doi.org/http://www.nova.edu/ssss/QR/QR15-3/qid.pdf

[19] McNamara, C., 2009. General guidelines for conducting interviews. Online. http://managementhelp.org/evaluatn/intrview.htm. Retrieved on 15th March, 2016.

[20] Malone, D.M., 1983. Small unit leadership: A common sense approach (3th ed.), US: Presido Press.

[21] Alberts, D.S. and R.E. Hayes, 2006. Understanding command and control. Washington D.C: CCRP.

[22] Ericsson, K.A., M.J. Prietula and E.T. Cokely, 2007. The making of an expert. Harvard Business Review, $1-9$. Online. https://hbr.org/2007/07/themaking-of-an-expert. Retrieved on $12^{\text {th }}$ February 2016. 